Relations industrielles

Industrial Relations

\title{
In Memoriam - Eugene Forsey 1904 - 1991
}

James Thwaites

Volume 46, numéro 2, 1991

URI : https://id.erudit.org/iderudit/050670ar

DOI : https://doi.org/10.7202/050670ar

Aller au sommaire du numéro

Éditeur(s)

Département des relations industrielles de l'Université Laval

ISSN

0034-379X (imprimé)

1703-8138 (numérique)

Découvrir la revue

Citer ce document

Thwaites, J. (1991). In Memoriam - Eugene Forsey 1904 - 1991. Relations industrielles / Industrial Relations, 46(2), 275-276.

https://doi.org/10.7202/050670ar

Tous droits réservés @ C Département des relations industrielles de l'Université Laval, 1991
Ce document est protégé par la loi sur le droit d'auteur. L'utilisation des services d'Érudit (y compris la reproduction) est assujettie à sa politique d'utilisation que vous pouvez consulter en ligne.

https://apropos.erudit.org/fr/usagers/politique-dutilisation/ 


\section{In memoriam}

\section{EUGENE FORSEY 1904-1991}

With the publication of his autobiographical $A$ Life on the Fringe, Eugene Forsey came back into public attention. In a sense, however, he had never been out of contact with the public. Ever ready to comment on socioeconomic and political questions, he had always been something of a favourite with the media.

Born on shipboard en route to Grand Bank, Newfoundland, in 1904, Eugene Forsey would later study at McGill University in Montreal and Balliol College, Oxford. He came out of an academic tradition where economists and political scientists still worked together in the same professional association and he made contributions in both of these areas. His first two works were typical in this sense: Economic and Social Aspects of the Nova Scotia Coal Industry and The Royal Power of Dissolution of Parliament in the British Commonwealth. He also developed a strong taste for reform ideas and politics which led him to work with the League for Social Reconstruction and participate in its programme published during the 1930's as Social Planning for Canada, a virtual blueprint for the CCF during the depression years. Later publications included Towards the Christian Revolution and Freedom and Order. During the last part of his career he produced the voluminous Trade Unions in Canada, after twenty years of researching and writing, and through it contributed to the orientation and training of numerous young enthusiastic graduate students like the present writer. His final work, A Life on the Fringe, is biographical in nature. During the course of his career he also published numerous articles in Relations industrielles/Industrial Relations, the Canadian Journal of Economics and Political Science, and the more popular, socially engaged Canadian Forum. He also contributed substantially to the founding of the journal Labour/Le Travailleur during the mid-1970's.

Eugene Forsey had his own style of writing. His vocabulary was a special mixture of standard Canadian English, sprinkled generously with British and Newfoundland expressions. On occasion this could be problematical. While going through the final phases of publishing Trade Unions in Canada, Eugene complained to me one day in Ottawa about a young editor at the U. of T. press who had proceeded to "translate" his book into "standard" canadianese. The unfortunate editor received numerous pages of justification of those expressions from the author and beat a hasty retreat. The book came out as originally written. Anyone who asked him for advice or comments on their research could also count on a speedy, voluminous reply as well. That was part of his way of doing thoroughly anything he got involved in. 
Eugene Forsey was much associated with the labour movement during his career. He served as research director of the Canadian Congress of Labour from 1942 to 1956, as research director of its successor, the Canadian Labour Congress, from 1956 to 1966, and as director-special projects of the CLC from 1966 to 1969 . During these crucial twenty-seven years, he influenced the labour movement and in turn it influenced him. (The idea, incidentally, for Trade Unions in Canada was born in this context, initially as a CLC centennial project, which mushroomed subsequently because of the incomplete nature of research on unions in Canada at that time.) Later he served with the Senate of Canada from 1970 to 1979 , contributing regularly to its debates. Eugene also found time to pursue his university interests by teaching economics at McGill and at Carleton University, as well as by directing theses. He also served on the Board of Governors at Trent University (1966-1973) and later as Chancellor there (1973-1977).

Eugene Forsey was no stranger to politics. His orientation, though, was more toward certain principles than toward specific parties. He first worked within the fledgling CCF during the 1930's and 1940's, running for election in 1948 . He openly aligned himself with John Diefenbaker's Tories toward the end of the 1950's to the dismay of his colleagues at the CLC, and he found himself close to Pierre Elliott Trudeau's Liberals during the 1970 's. He became a fervent advocate of bilingualism, insisting on the use of French whenever possible, and carried this even to the personal level acting as sidesman of a French-language United Church parish in downtown Ottawa. Eugene defended French in English Canada, for example during a public debate in the prairies, and English in Québec as required. In this, he shared the preoccupations of his longtime acquaintance and friend Gérard Dion.

Eugene Forsey was much appreciated. Even as a student he won the coveted Rhodes Scholarship and Guggenheim Fellowship. As a mature scholar, activist and independent thinker, he was awarded a total of thirteen honorary doctorates from 1962 to 1979: nine LL.D.'s (UNB, McGill, Saskatchewan, Toronto, Waterloo, Dalhousie, York, Carleton, Queen's), three D. LITT's (Memorial, Acadia, Trent), and one D.C.L. (Mount Allison). He was also received as a fellow by the Royal Society of Canada and created a member of the Order of Canada.

It was difficult toward the end. Nevertheless, ever active, he published his last study during the final year of his life, and could be found regularly working in an office accorded him by the present government in the Senate office building on Wellington Street. He will be missed both by friends and adversaries for his convictions, frank discussion and command of subject.

James Thwaites

Département des relations industrielles

Université Laval 